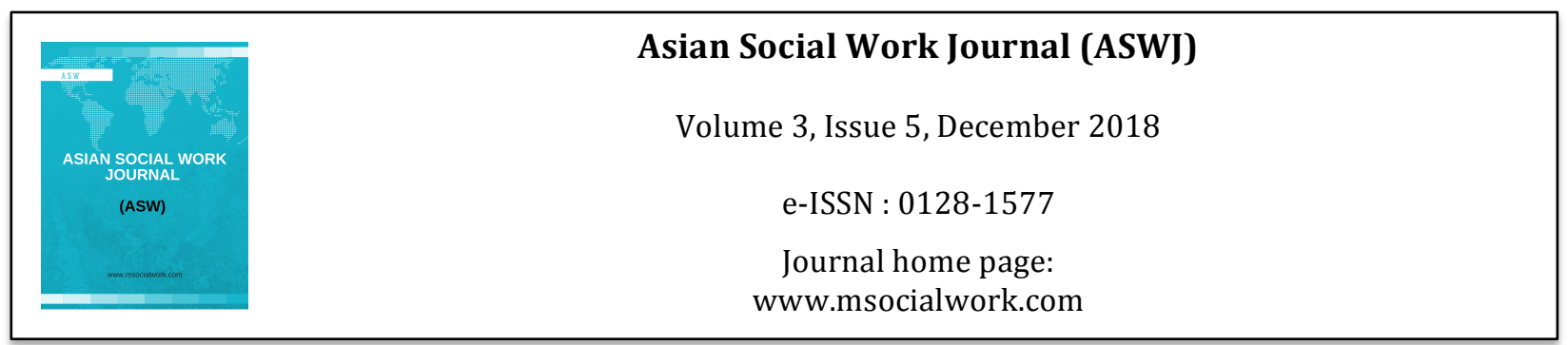

\title{
Peranan dan Tanggungjawab Ibu Bapa dalam Pengasuhan Anak dan Remaja
}

\author{
Habibie Bte Hj Ibrahim1, Mazni Mustapha1, Joki Perdani1, Puteri Hayati Megat Ahmad1, Nurul \\ Hudani Md Nawi ${ }^{1}$ \\ 1Fakulti Psikologi dan Pendidikan, Universiti Malaysia Sabah (UMS)
}

Corrrespondence: Habibie Bte Hj Ibrahim (hibrahim@ums.edu.my)

\begin{abstract}
Abstrak
Artikel ini merupakan kertas konsep yang menekankan peranan dan tanggungjawab ibu bapa terhadap anak-anak terutamanya anak yang sedang meningkat remaja. Dewasa ini, Malaysia menunjukkan peningkatan penglibatan anak remaja di dalam masalah sosial. Peningkatan ini dipercayai kerana kurangnya peranan dan tanggungjawab yang dimainkan oleh ibu bapa apatah lagi kepada ibu bapa yang berkerjaya. Selain daripada itu, masalah lain yang ditunjukkan kepada peningkatan permasalahan sosial adalah masalah kurangnya komunikasi antara ibu bapa dan anak. Justeru, kertas kerja ini juga turut menekankan peranan komunikasi di dalam membina hubungan yang baik dan harmoni antara ibu bapa dan anak remaja selain daripada mengupas isu peranan dan tanggungjawab ibu bapa terhadap anak-anak dan keluarga.
\end{abstract}

Kata kunci: masalah sosial, remaja, hubungan, komunikasi, anak-ibubapa

\begin{abstract}
This conceptual paper emphasizes roles and responsibilities of parents towards children particularly teenagers. Currently, Malaysia shows an increasing of teenagers' involvement in social problems. The increasing of social problem is believed due to lack of roles and responsibilities played by parents especially for dual-career families. Besides that other problem contributed to the increasing of social problems was less communication between parents and children. Therefore, this paper also emphasizes the role of communication in effort to build a good and harmoniousrelationship between parents and teenagers and outlines the roles and responsibilities of parents towards children and families.
\end{abstract}

Key words: social problem, teenager, relationship, communication and children-parents

\section{Pengenalan}

Praktis kerja sosial bersama individu (anak/anak remaja) dan keluarga meletakkan kehendak dan aspirasi kanak-kanak (the child's voice) sebagai penting dalam praktis kerja sosial. Pekerja sosial hendaklah cekap di dalam ilmu dan teori berkenaan perkembangan kanak-kanak dan ini termasuklah kehendak dan aspirasi kanak-kanak remaja masa kini. Pekerja sosial kanak-kanak dan keluarga memegang salah satu peranan sebagai educator iaitu mendidik dan membimbing klien kanak-kanak dan keluarga di dalam membentuk keharmonian di dalam keluarga seperti yang diinginkan oleh ahliahli di dalam setiap keluarga. 
Masalah sosial dalam kalangan kanak-kanak remaja semakin berleluasa dan membimbangkan. Banyak faktor penyebab berlakunya masalah sosial dalam kalangan remaja antaranya faktor diri sendiri, pengaruh rakan sebaya dan permasalahan persekitaran sekolah, juga latar keluarga (Sharif \& Mohamad Roslan, 2011; Mustaffa, Hassan, \& Ramli, 2004). Sebagai langkah menangani masalah sosial dalam kalangan remaja, Sipon (2001) mengemukakan strategi-strategi mengatasi konflik antara remaja dan ibu bapa yang seterusnya dapat mengurangkan risiko berleluasanya masalah sosial. Strategi tersebut termasuklah mencari penyelesaian masalah bersama, memberikan kasih sayang sejati dan layanan mesra kepada anak-anak serta memperuntukkan masa yang secukupnya untuk anak-anak. Strategistrategi ini boleh dilihat sebagai strategi yang bersifat seimbang di mana kanak-kanak juga dimasukkan sebagai satu pihak yang perlu diambil kira tentang kewujudan mereka di dalam keluarga.

Konvensyen PBB mengenai Hak Kanak-Kanak memberi banyak hak kepada semua kanak-kanak dan orang muda untuk melindungi, mempromosikan kesejahteraan dan membantu kanak-kanak membangunkan potensi unik mereka. Ini termasuklah hak: 1) Keselamatan kanak-kanak; 2) dilindungi dan hidup bebas daripada keganasan, penyalahgunaan atau kemudaratan (ini termasuk menyaksikan keganasan dan penyalahgunaan); 3) dibesarkan oleh ibu bapa mereka dalam keluarga, melainkan jika bukan keinginan kanak-kanak; 4) untuk menyatakan pandangan mereka (kanak-kanak) dan memaklumkan mereka (kanak-kanak) dalam hal-hal yang memberi kesan kepada mereka (kanakkanak); 5) diberikan keputusan yang memberikan kesan kepada mereka (kanak-kanak) iaitu dengan kepentingan kanak-kanak (yang terbaik); 6) untuk diperlakukan dengan maruah, hormat dan adil serta; 7) bebas dari diskriminasi, buli dan apa-apa jenis gangguan. Deklarasi nombor empat (4) dan lima (5) di atas dilihat seakan-akan memberi ruang yang seimbang kepada kanak-kanak bagi menyuarakan pandangan dan keinginan mereka. Ini termasuklah di dalam soal penjagaan dan perlindungan oleh ibu bapa dan penjaga, orang dewasa yang bertanggungjawab dan pihak profesional. Praktis kerja sosial bersama individu (anak/remaja) dan keluarga meletakkan kehendak dan aspirasi kanak-kanak (the child's voice) sebagai penting dalam praktis kerja sosial. National Children's Bureau (2006) memberikan garis panduan - The Child's Voice: Practice Guidance di mana menurut mereka child's voice membawa maksud:

"Spending time with children, talking to them, and making sure that you are actively listening and taking seriously what they say is an essential safeguarding activity."

Sejajar dengan definisi child's voice di atas, pekerja sosial hendaklah cekap di dalam ilmu dan teori berkenaan perkembangan kanak-kanak dan ini termasuklah kehendak dan aspirasi kanak-kanak remaja masa kini. Justeru, mengambil kira pandangan dan keinginan kanak-kanak apatah lagi anak-anak remaja di dalam soal penjagaan dan perlindungan seakan-akan lebih memberikan kesan yang positif.

\section{Hubungan Anak dan Ibu Bapa}

Bagi mengulas tentang kehendak anak-anak remaja terhadap peranan dan tanggungjawab ibu bapa ke atas mereka, artikel ini menyentuh permasalahan sosial anak remaja masa kini. Penulisan menyentuh tentang faktor penyumbang kepada berlakunya masalah sosial atau terlibatnya anak-anak di dalam kancah pemasalahan sosial. Adakah anak remaja terlibat di dalam masalah sosial kerana kurangnya peranan dan tanggungjawab yang dimainkan oleh ibu bapa? Atau, adakah penglibatan anak remaja berpunca daripada ibu bapa yang gagal memenuhi kehendak atau kurang mahir di dalam memahami anak-anak apatah lagi anak remaja? Lima faktor masalah tingkah laku kanak-kanak adalah seperti faktor persekitaran, emosi, didikan ibu bapa, kemahiran sosial dan penderaan (Che Ahmad, Ghani, Omar, \& Md Isa, 2010). Kajian oleh Azizan, Ismail, Abu Bakar, Dimon dan Surtahman (2015), menfokuskan kepada permasalahan remaja yang sering dikaitkan dengan perilaku delinkuen. Mereka ini dilabelkan sebagai golongan yang suka memberontak dan tidak mematuhi undang-undang serta terjerumus dalam kesalahan dan jenayah seperti mencuri, penyalahgunaan dadah, gangsterisma dan vandalisma. Kajian yang dilakukan oleh Sharif dan Mohamad Roslan (2011) mendapati bahawa faktor diri sendiri (anak/anak remaja) paling mempengaruhi remaja terlibat dalam masalah sosial berbanding pengaruh rakan sebaya dan pemasalahan persekitaran sekolah. Walau bagaimanapun, analisis 
mendapati latar keluarga bukan faktor penting remaja terlibat dalam masalah sosial (Sharif, \& Mohamad Roslan, 2011).

Remaja adalah masa transisi atau peralihan dari zaman kanak-kanak menuju zaman dewasa yang menampakkan adanya perubahan dari aspek fizikal, psikik, dan psikososial. Zaman remaja juga diertikan sebagai zaman di mana seseorang menunjukkan tanda- tanda akil baligh dan seterusnya hingga tercapainya kematangan seksual (Sianturi, 2016). Di usia remaja awal iaitu di umur 13-15 tahun, adalah usia yang sukar difahami oleh kebanyakkan ibu bapa kerana kurangnya pengendalian terhadap ego (Panjaitan \& Daulay, 2012). Menurut Pertubuhan Kesihatan Sedunia (WHO), remaja adalah dalam kalangan yang berumur 10 tahun sehingga 19 tahun. Ia berbeza dengan belia yang berumur 15 tahun sehingga 30 tahun (Utusan online, 18 Nov 2014). Pada peringkat usia ini, remaja mempunyai perasaan ingin tahu yang tinggi. Justeru apa-apa sahaja perkara baru yang terjadi di sekeliling boleh mengundang perasaan ingin tahu dalam kalangan remaja. Secara tidak langsung membuatkan anak remaja terdorong untuk mencuba dan melakukan perkara-perkara tersebut. Remaja harus juga dilihat sebagai satu proses sosial yang membabitkan institusi keluarga, persekolahan, pekerjaan, dan tidak kurang penting adalah media. Perlakuan remaja bukan sahaja dipengaruhi oleh aspek objektif institusi sosialisasinya, tetapi juga oleh aspek subjektif bagaimana remaja mentafsirkan keadaan di sekeliling mereka (Samsudin A Rahim dalam Azizan, et al., 2015).

Suasana bahagia di dalam hubungan keluarga menjadi keinginan dan cita-cita setiap ahli keluarga tidak kira anak mahupun ibu bapa/penjaga. Kebahagiaan merupakan suatu yang dirindui oleh setiap orang kerana kebahagiaan merupakan kebaikan paling besar di antara segala kebaikan yang ada (Muhammad, 1966). Dari sudut perspektif Islam, di dalam mencapai kebahagiaan keluarga, sebuah keluarga memerlukan seorang pemimpin terbaik (Al-Yasin, 1983). Imam al-Ghazali (1058M-1111M), menjelaskan, kebahagiaan ditafsirkan sebagai penyatuan antara ilmu, amal, rohani dan jasmani (Muhammad, 1923). Ibu bapa perlu memainkan peranan yang penting dalam memberikan keperluan rohani anak-anak mereka. Sesuai dengan kedudukan rumah sebagai institusi pendidikan pertama, ibu bapalah yang bertanggungjawab memberikan pendidikan agama, iman dan akhlak (Yahaya, 2017).

Konflik di antara anak remaja dan ibu bapa biasanya berlaku atas beberapa faktor seperti sikap ibu bapa, tahap pengetahuan ibu bapa, harapan ibu bapa dari segi pembelajaran dan persepsi ibu bapa pada jangka masa panjang (Sipon, 2001). Selain daripada itu, Sipon (2001) menambah faktor kanak-kanak sendiri seperti tuntutan untuk kebebasan, pertentangan nilai antara ibu bapa dengan rakan sebaya, matlamat ibu bapa dan sikap remaja terhadap keluarga juga menyumbang kepada berlaku konflik antara anak remaja dan ibu bapa. Komunikasi berkesan adalah asas kepada kecemerlangan dalam kehidupan berkeluarga. Ali, Rahim dan Mustaffa (2008) telah menggariskan ciri-ciri optimum situasi berkomunikasi dalam keluarga. Mereka menyatakan bahawa komunikasi yang terbaik dalam keluarga mestilah dan melibatkan rasa ingin mendengar dan berkongsi. Fungsi komunikasi yang pertama ialah hubungan yang rapat dan intim adalah amat penting kepada kebahagiaan dan kesejahteraan jiwa manusia.

Sering kali ibu bapa malas atau susah untuk berkomunikasi dengan anak. Meskipun setiap hari berjumpa dengan seluruh ahli keluarga tetapi belum tentu terjadi komunikasi dari hati ke hati antara satu sama lain. Komunikasi daripada kanak-kanak selalu melibatkan bahasa bukan lisan kerana tahap penyampaian mereka adalah terhad. Sehubungan dengan itu, persoalan penting berkaitan kehendak kanak-kanak remaja terhadap ibu bapa atau penjaga mereka perlu dibahas termasuklah; i) Apakah kehendak/harapan kanak-kanak remaja ke atas asuhan, penjagaan dan perlindungan oleh ibubapa mereka terhadap mereka? ii) Apakah manfaat yang diperoleh oleh kanak-kanak remaja sekiranya ibu bapa mempunyai ilmu dan kemahiran di dalam mengasuh, menjaga dan memberikan perlindungan seperti yang dikehendaki/diingini oleh anak remaja?

\section{Peranan dan Tanggungjawab Ibu Bapa}

Pembinaan kepercayaan seorang anak dalam menerima kasih sayang ibu bapa di sepanjang pengasuhan memerlukan hubungan interaksi yang berterusan. Sepanjang perjalanan anak menuju ke alam dewasa 
biasanya boleh menimbulkan masalah yang tersendiri bagi setiap anak. Hubungan anak-ibu bapa yang tidak harmoni, pemaksaan kehendak dan kedudukan ibu bapa sebagai pemilik anak, ini boleh menjerumuskan anak sebagai mangsa perlakuan ibu bapa (Juniawati, 2015). Keadaan ini dikhuatiri boleh menimbulkan kesan kepada anak dalam berbagai bentuk yang seterusnya menjadi topik dan isu di dalam masyarakat. Keganasan pada kanak-kanak boleh mencacatkan perkembangan seorang kanakkanak di dalam keluarga dan juga di persekitarannya seperti yang ditunjukkan oleh peningkatan kes keganasan dan jenayah sosial dalam kalangan kanak-kanak (Juniawati, 2015).

Menyentuh soal perundangan berkenaan tanggungjawab ibu bapa terhadap anak-anak, Abdul Shukor (2016) mencadangkan agar undang-undang berkaitan tanggungjawab ibu bapa di Malaysia perlulah dirujuk kepada aspek undang- undang Islam (bagi mereka yang beragama Islam). Manakala, bagi ibu bapa yang bukan Islam, tanggungjawab ibu bapa perlu dilihat daripada aspek adat budaya setempat yang masih diamalkan sehingga kini. Secara tidak langsung, polisi-polisi yang diperkenalkan akan memantapkan lagi Dasar Keluarga Negara yang diluluskan oleh kerajaan Malaysia pada Disember 2010 dan Dasar dan Pelan Tindakan Kanak-kanak Negara (2012) mengikut acuan dan persekitaran di Malaysia (dalam Abdul Syukor, 2016).

Che Mat (1994), memberikan penegasan tentang tanggungjawab ibu bapa dalam menentukan dan mencorakkan perlakuan anak. Beliau menegaskan dengan memberikan asuhan yang positif adalah amat penting dalam melahirkan keluarga yang harmoni. Pandangan Che Mat (1994) disokong oleh Kamsah dan Ismail (1996) di mana menurut Kamsah dan Ismail (1996) ibu bapa berperanan sebagai penjaga, pendidik, pengasuh, pemimpin, perawat, penasihat dan kaunselor dari segi fizikal, mental dan rohani anak-anak. Yahaya dan Nam (2010) pula menekankan komunikasi antara ibu bapa dan anak-anak termasuklah mendengar, memahami masalah dan ketakutan anak-anak, membantu anak-anak memerlukan dan menjelaskan dengan tegas perkara yang betul dan perkara yang salah. Cara komunikasi adalah perkara penting yang boleh mengeratkan hubungan sesama ibu bapa dan anak (Yahaya \& Nam, 2010). Ali, Mad Rahim dan Mustaffa (2008) juga menekankan peranan komunikasi di dalam keluarga. Mereka menekankan kepentingan komunikasi dalam pembentukan sebuah keluarga yang bahagia berdasarkan kepada situasi masyarakat kini yang sedang mengalami perubahanperubahan besar akibat proses pemodenan dan pembangunan ekonomi. Menurut mereka institusi kekeluargaan boleh menjadi lebih kukuh seandainya ibu bapa dan anak-anak pandai berkomunikasi sehingga menyebabkan keseluruhan ahli keluarga merasakan dirinya dicintai, dikasihi, dihargai dan dimuliakan.

Di dalam Islam kasih sayang ibu bapa kepada anak telah diatur. Kewajipan ini diberikan sedari anak di dalam kandungan lagi. Seorang anak mempunyai hak untuk menerima rawatan dan pemeliharaan (alhadanah) daripada ibu bapa difahami sebagai pemeliharaan secara menyeluruh, baik dari segi kesihatan fizikal, mental, dan perkembangan pengetahuannya (Lajnah Pentashih Mushaf Al-qur'an, 2014, dalam Juniawati, 2015). Ibu bapa perlu memainkan peranan yang penting dalam memberikan keperluan rohani anak-anak mereka. Sesuai dengan kedudukan rumah sebagai institusi pendidikan pertama, ibu bapalah yang bertanggungjawab memberikan pendidikan agama, iman dan akhlak (Yahaya \& Nam, 2010). Mengikut pandangan Islam juga, kejatuhan moral anak-anak berpunca daripada ibu bapa yang lupa tanggungjawab mereka. Masalah sosial yang berlaku ke atas anak-anak disebabkan ibu bapa yang kurang peka dan kurang di dalam memberikan perhatian yang tinggi terhadap tingkah laku dan peribadi anak-anak. Ibu bapa berpendapat sudah cukup dengan menyediakan keperluan makanan dan tempat tinggal yang selesa kepada anak-anak tetapi tidak menunjukkan keperihatinan yang tinggi (Yahaya, 2017). Yahaya (2008) berpandangan bahawa ibu bapa seharusnya boleh memainkan pelbagai peranan dalam membentuk disiplin dan peribadi anak-anak. Kecuaian ibu bapa untuk memahami peranannya yang sebenar menjadikan anak-anak hilang panduan dan keliru dalam menjalani hidupnya.

Namun, remaja dari semua peringkat umur perlu juga diberi tanggungjawab yang sesuai mengikut peringkat umur dan kematangan mereka, mengetahui had batasan dan mempelajari kesan dan akibat daripada perilaku mereka. Mereka perlu mengetahui tentang keselamatan umum, mempunyai peluang untuk mencerminkan tingkah laku pengambilan risiko dan menjadi lebih bersedia sekiranya mereka mendapati diri mereka dalam bahaya. Selain daripada itu, anak remaja dan anak muda memerlukan tidur yang mencukupi, diet seimbang, akses kepada sukan dan hobi, dan masa untuk berehat dengan 
keluarga dan rakan-rakan. Mereka juga memerlukan maklumat yang tepat mengenai pertumbuhan dan perkembangan mereka (Department of Health and Human Services, USA, 2011). Department of Health and Human Services, USA (2011) menyarankan tiga saranan bagaimana ibu bapa dan anakanak remaja boleh menikmati masa menyeronokkan bersama iaitu: 1) Tunjukkan bahagian yang menyeronokkan tentang anda sebagai ibu bapa kepada anak remaja; 2) kembangkan minat bersama dan: 3) berikan ruang kepada anak remaja anda. Bagi saranan yang pertama bermaksud semasa anakanak masih memerlukan ibu bapa, bukan rakan, tunjukkan kepada anak-anak bahawa ibu bapa adalah seseorang yang menyeronokkan dan menarik. Kongsi keseronokan ibu bapa tentang hobi yang ada, beritahu anak-anak tentang aspek-aspek aktiviti yang dilakukan yang mungkin boleh menarik minat mereka dan berceritalah tentang aktiviti-aktiviti yang ibu bapa seronok lakukan. Biarkan anak-anak melihat ibu bapa sebagai seorang individu, bukan hanya sebagai ibu bapa. Saranan kedua pula bermaksud, seorang anak remaja yang meminati sukan bola sepak sudah tentu seronok berbicara tentang bola sepak bersama ibu bapa mereka. Begitu juga tentang hobi dan lain-lain minat anak-anak. Walaupun ibu bapa dan anak-anak tidak meminati perkara atau hobi yang sama, ibu bapa adalah diharapkan menunjukkan perasaan ingin tahu dan mahu mengembangkan minat dan cuba untuk mencari persamaan. Manakala bagi saranan ketiga pula ianya bermaksud sebagai ibu bapa jangan terlalu memaksa sekiranya anak-anak remaja tidak berminat atau tidak menunjukkan rasa ingin berbual atau sekiranya anak remaja lebih ingin bersama rakan-rakan mereka mahupun bersendirian. Anak remaja juga mempunyai hak privasi (lingkungan yang selamat), seperti ibu bapa. Tiga saranan seperti yang disebutkan ini bersifat seimbang dan mempertimbangkan kewujudan anak remaja di dalam keluarga. Ibu bapa diminta untuk melihat anak remaja sebagai satu entiti yang hidup yang perlu diberikan kedudukan yang sewajarnya di dalam keluarga.

Terdapat beberapa faktor penting dapat dikaitkan dengan penglibatan remaja di dalam gejala sosial. Faktor yang pertama adalah kefungsian institusi kekeluargaan di mana remaja tersebut menerima proses sosialisasi dan pembesaran. Keluarga bahagia itu ialah satu keluarga yang dapat merasa senang terhadap satu sama lain dan terhadap hidup sendiri serta mempunyai objektif pembinaan keluarga yang jelas dan positif (Jaapar \& Azahari, 2011). Kajian oleh Bronstein (1994) menunjukkan ibu bapa yang mesra dan menyokong akan memberi kesan terhadap tingkah laku positif dalam kalangan anak-anak, manakala jenis ibu bapa yang suka menghukum akan memberi kesan terhadap tingkah laku negatif dalam kalangan anak-anak (dalam Contreras, Kerns, Neal-Barnett, 2000). Justeru, ibu bapa yang gagal memainkan peranan sebagai 'role model' kepada anak mereka akan memberi kesan yang negatif kepada perkembangan mereka (Ishak, 2018). Selain itu, dengan peningkatan keluarga dwi-kerja dan peningkatan golongan wanita dalam sektor pekerjaan turut memberi kesan kepada kefungsian institusi keluarga itu sendiri. Ibu bapa yang sibuk bekerja dan jarang berada di rumah menyebabkan anak-anak bosan untuk berada di rumah dan gemar untuk menghabiskan masa mereka di tempat-tempat yang tidak berfaedah. Secara tidak langsung, kebarangkalian untuk mereka ini untuk melakukan perkara yang di luar pengawasan ibu bapa adalah tinggi (Ishak, 2018). Ishak (2018) menambah lagi bahawa senario ibu bapa yang sibuk bekerja juga menimbulkan keadaan hubungan antara ibu bapa dan anak semakin renggang apabila ibu bapa yang keluar seawal pagi dan pulang lewat malam tidak dapat meluangkan masa bersama anak mereka. Keadaan ini turut mengakibatkan kurangnya interaksi dan komunikasi antara ibu bapa dan anak mereka terutama sekali anak yang memerlukan ibu bapa mereka untuk berkongsi masalah dan meminta pendapat untuk sesuatu hal yang dihadapi oleh mereka. Kesan daripada interaksi dan komunikasi antara ibu bapa dan anak ini dapat dilihat daripada kajian yang dilakukan oleh Barnes dan Olson (1985) yang mendapati komunikasi yang baik antara ibu bapa dan remaja akan menyebabkan hubungan keluarga semakin rapat, wujud kasih sayang dan proses penyelesaian masalah boleh berlaku dengan mudah. Jelas di sini bahawa fungsi komunikasi dalam keluarga dapat memastikan keharmonian keluarga yang terus terpelihara.

Ibu bapa mempengaruhi kejayaan anak/anak remaja khususnya kejayaan anak/anak remaja di dalam pelajaran. Ini adalah kerana ibu bapa yang sentiasa memberi sokongan dan galakan sehingga anak-anak timbul minat, bersemangat dan menunjukkan ketekunan serta keyakinan diri di dalam proses pembelajaran. Ibu bapa jugalah yang menentukan pola-pola tingkah laku remaja. Faktor-faktor seperti dorongan dan galakan, disiplin di rumah, hubungan mesra antara ibu bapa dan anak serta hubungan keluarga yang utuh dapat memberi kesan ke atas pembentukan personaliti, motivasi dan pencapaian akademik anak/anak remaja yang masih bergelar pelajar (Mohamad, 2018). Oleh itu, ibu bapa yang 
kurang memainkan peranan mereka yang sepatutnya dan sewajarnya di dalam pembentukan dan perkembangan personaliti atau sahsiah anak/anak remaja menyebabkan konflik sahsiah remaja tersebut. Ini boleh menyebabkan remaja mencari jalan keluar dengan bersifat agresif dan memberontak. Remaja yang mempunyai sifat tersebut lebih gemar menghabiskan masa mereka di luar rumah kerana berasa terkongkong berada di dalam rumah (Mohamad, 2018). Punca utama penglibatan remaja dalam gejala sosial adalah kurangnya perhatian dan kasih sayang daripada ibu bapa serta keluarga. Justeru, bagi mengatasi masalah ini daripada terus berlarutan, ibu bapa perlu memberi perhatian, bimbingan serta kasih sayang kepada anak-anak mereka terutamanya anak-anak remaja. Sekiranya ibu bapa kurang atau tidak memberi kasih sayang yang secukupnya, maka dikhuatiri anak-anak akan mencari kasih sayang yang diperlukan daripada orang lain yang dikhuatiri hanya boleh membawa kepada perkara yang negatif.

Terdapat juga pernyataan daripada hasil penyelidikan menunjukkan remaja yang bermasalah seakanakan menuding jari kepada ibu bapa, kononnya ibu bapa tidak memberi perhatian wajar kepada mereka kerana sibuk menumpukan urusan kerja. Ibu bapa dan anak remaja kekurangan masa bersama, kasih sayang yang anak remaja harapkan pula diganti dengan kemewahan dan wang ringgit. Terdapat juga ibu bapa yang menyerahkan tugas dan tanggungjawab mereka kepada pembantu rumah, guru atau pendidik yang telah dibayar gaji. Dari perspektif ibu bapa pula, mereka seolah-olah keliru dengan kenyataan anak-anak mereka. Lebih buruk lagi apabila mereka menuding jari kepada pihak lain seperti sekolah yang kononnya gagal melahirkan pelajar yang berdisiplin. Kita telah ketahui antara punca utama dalam penglibatan remaja dalam gejala sosial hari ini adalah kurangnya perhatian dan kasih sayang daripada ibu bapa dan keluarga. Bagi mengatasi masalah ini daripada terus berlarutan, ibu bapa perlu memberi perhatian, bimbingan dan kasih sayang kepada anak-anak mereka lebih-lebih lagi anakanak pada usia peringkat remaja. Sekiranya ibu bapa kurang atau tidak memberi kasih sayang yang secukupnya, dikhuatiri anak-anak mencari kasih sayang tersebut dari orang lain seperti rakan sebaya (Rohanizan, 2018).

\section{Kesimpulan}

Walaupun takrifan dan istilah tanggungjawab ibu bapa masih samar-samar, terdapat satu keperluan untuk para penggubal dasar menegaskan kepentingannya dan mengenalpasti tanggungjawab ibu bapa dalam membina dasar polisi keluarga. Kerajaan Malaysia perlu mengambil inisiatif untuk meningkatkan penyertaan ibu bapa, terutamanya golongan ibu bapa yang masih muda dalam menangani isu keibubapaan dan pada masa yang sama, menggalakkan perlindungan kanak-kanak dalam unit keluarga (Shukor, 2016). Peranan dan tanggungjawab ibu bapa dalam mendidik anak pada zaman kini adalah pelbagai (Yahaya, 2008). Ini termasuklah peranan dalam membentuk disiplin dan peribadi anak-anak. Menurut Yahaya (2008), kecuaian ibu bapa untuk memahami peranannya yang sebenar menjadikan anak-anak hilang panduan dan keliru dalam menjalani hidupnya. Beliau juga mengingatkan ibu bapa bahawa jangan menyalahkan anak-anak apabila mereka memilih orang lain untuk dicontohi. Justeru, adalah dicadangkan tentang keperluan mendengar dan mempertimbangkan kehendak dan kemahuan di dalam penjagaan dan perlindungan kanak-kanak remaja mengikut perspektif kanak-kanak remaja itu sendiri.

\section{Rujukan}

Abdul Shukor, S. (2016). Tanggungjawab Ibu Bapa Dalam Melindungi Kanak-Kanak Menurut Undang-Undang Malaysia: Satu Tinjauan Awal. Malaysia Journal of Syariah and Law, 4, 1-10.

Ali, A., Md Rahim, I., dan Mustaffa, M.S. (2008) Peranan Komunikasi dalam Hubungan Kekeluargaan. Muat-turun daripada https://www.slideshare.net/AtieAli/asiah-ali2008peranankomunikasidalamhubungankekeluargaan

Al-Yasin, J. (1983), Faylasufan Ra'idan: al-Kindi wa al-Farabi. Bayrut: Dar al-Andalus, c. 2, m.s. 8283.

Azizan, N.I., Ismail, N., Abu Bakar, S.A., Dimon, Z. dan Surtahman, A.W. (2015). Permasalahan Sosial Dalam Kalangan Remaja Di Selangor: Satu Tinjauan. Seminar Antarabangsa Akidah, 
Dakwah Dan Syariah 2015 (IRSYAD2015), Kuala Lumpur, 12-13 Oktober 2015. Muat-turun daripada http://conference.kuis.edu.my/irsyad/eproceeding/2015/1023-irsyad-2015.pdf

Barnes, H.L., and Olson, D. H. (1985). Parent-Adolescent Educationand the Circumplex Model. Family Development and the Child, Apr., 1985, 438-447

Che Ahmad, A., Ghani, M.Z., Omar, S., dan Md Isa, Z. (2010). Kanak-Kanak Bermasalah Tingkah Laku. Muat-turun daripada https://www.researchgate.net/publication/291997651 Kanakkanak Bermasalah Tingkahlaku

Che Mat, R. (1994). Remaja Lepak Semua Pihak Perlu Campur Tangan. dalam Dewan Siswa, April, hlm. 30-43.

Contreras, J.M., Kerns, K.A., Neal-Barnett, A.M. (2000). Latino Children and Families in the United States: Current Research and Future Directions. Westport: Praeger Publisher

Department of Health and Human Services, USA .(2011). Positive Parenting Strategies for the Teenage Years. Muat turun daripada www.wfm.noaa.gov/pdfs/ParentingYourTeen_Handout1.pdf

Ishak, I. (2018). Modenisasi Dan Wacana Mengenai Penglibatan Remaja Dalam Gejala Sosial. Muatturun daripada https://www.academia.edu/17331717/MODENISASI_DAN_MASALAH_SOSIAL_REMAJA

Jaapar, N.Z dan Azahari, R. (2011). Model Keluarga Bahagia Menurut Islam. Jurnal Fiğh, No. 8 2544

Juniawati, J. (2015). Komunikasi Dalam Keluarga: Upaya Strategis Mencegah Kekerasan Pada Anak. Muat-turun daripada https://jurnaliainpontianak.or.id/index.php/raheema/article/.../130

Kamsah, M.F., \& Ismail, R. (1996). Kecemerlangan Mendidik Anak, Kuala Lumpur: Utusan Publication \& Distributors Sdn. Bhd.

Mohamad, R. (2018). Gejala Sosial di Kalangan Remaja. Muat-turun daripada https://www.academia.edu/12537670/GEJALA_SOSIAL_DI_KALANGAN_REMAJA

Muhammad, A.H.M. (1923), Mizan al-'Amal. al-Qahirah: Muhy al-Din Sabri al-Kurdi, m.s. 304-309.

Muhammad, A.N.M. (1966), Kitab Tanbih 'ala Sabil al-Sa'adah. t.t.p: Matba'ah Majlis Da'irat alMa'arif al-Uthmaniyyah, m.s. 2.

Mustaffa, M.S., Hassan, Z., \& Ramli, J. (2004). Komuniti Remaja \& Permasalahan Sosial: Peranan Guru Sebagai Penolong Bantu Di Sekolah. Muat-turun daripada http://repo.uum.edu.my/1909/1/48.pdf

National Children's Bureau (2006). Communicating with Children. Muat-turun daripada https://www.ncb.org.uk/listing-tag/communicating-children

Panjaitan, D.S., dan Daulay, W. (2012). Pola Asuh Orang Tua Dan Perkembangan Sosialisasi Remaja Di Sma Negeri 15 Medan. Jurnal Keperawatan Holistik, 1, 40-46.

Sharif, Z. dan Mohammad Roslan, N. (2011). Faktor-Faktor Yang Mempengaruhi Remaja Terlibat Dalam Masalah Sosial Di Sekolah Tunas Bakti, Sungai Lereh, Melaka. Journal of Education Psychology \& Counseling, 1 Mac 2011, 115-140

Sianturi, S. (2016). Komunikasi Interpersonal Orang Tua Dan Anak Tentang Pendidikan Kesehatan Repdoruksi. Muat-turun daripada http://repository.usu.ac.id/handle/123456789/51726

Sipon, S. (2001). Peranan Ibu Bapa dalam Menangani Masalah Sosial Remaja. Muat-turun daripada https://www.researchgate.net/publication/280114584

Utusan online (2014). Had umur belia 15-30 tahun bermula 2018. Muat-turun daripada http://www.utusan.com.my/berita/nasional/had-umur-belia-15-30-tahun-bermula-2018-1.26083

Yahaya, A. (2017). Keluarga dalam Pembentukan Moral. Muat-turun daripada http://eprints.utm.my/id/eprint/6035/1/aziziyahmoral.pdf

Yahaya, A dan Nam, G.L. (2010). Peranan Ibu Bapa. Muat-turun daripada http://eprints.utm.my/id/eprint/10373/1/28.9 PERANAN IBU BAPA.pdf

Yahaya, A. (2008). Sejarah Sikap Pemeliharaan Kanakkanak: Stail Kekeluargaan, Pendidikan Kekeluargaan. Muat-turun daripada http://eprints.utm.my/id/eprint/6032/1/bukukeluarga.pdf 